\title{
PERSEPSI PELAKU KEKERASAN DALAM RUMAH TANGGA TERHADAP UU PKDRT NO 23 TAHUN 2004
}

\author{
Jamilah \\ Akmal Adicahya \\ Fakultas Syariah UIN Maulana Malik Ibrahim Malang \\ zhenit79@yahoo.com
}

\begin{abstract}
The Domestic Violence Act of Indonesia has been applied for 10 years. However, it seems this act does not reduce significantly the practice of domestic violence. Lawrence Friedman emphasizes that there is legal culture that influences legal system. It means that the acceptance of citizen influences the quality of legal system. This research shows that the offenders of domestic violence accept the regulation. Moreover, they consider this regulation as good act to implement. However, there are several factors that make them still practice violence toward their family. Less knowledge, public acceptance and psychological condition contribute to the level of obedience before the law. Therefore, citizens need a good and massive socialization from government about this regulation.

Sudah 10 tahun lebih undang-undang kekerasan dalam rumah tangga disahkan dan diterapkan di Negara Indonesia. Akan tetapi praktik kekerasan dalam rumah tangga masih terjadi. Hal ini menunjukkan bahwa terdapat permasalahan dalam tataran implementasinya. Lawrence Friedman mengungkapkan bahwa terdapat unsur budaya hukum yang sangat berpengaruh dalam tegaknya sistem hukum. Hal ini berarti bahwa penerimaan masyarakat terhadap aturan mempengaruhi penegakan hukum. Penelitian ini menunjukkan bahwa para pelaku kekerasan dalam rumah tangga menerima bahkan menganggap undang-undang ini sangat baik. Akan tetapi ada banyak hal yang menyebabkan mereka melakukan kekerasan. Ketidaktahuan, penerimaan publik, serta kondisi psikologis pelaku sangat mempengaruhi tingkat kepatuhan. Oleh karenanya, sosialisasi yang baik massif dan sangat penting untuk dilakukan oleh pemerintah.
\end{abstract}

Kata Kunci: Budaya hukum, perilaku hukum, KDRT, UU-PKDRT

Kekerasan dalam rumah tangga (KDRT) merupakan salah satu isu hukum yang berkembang di Indonesia. Perbuatan tersebut merupakan fenomena umum yang terus berkembang dari ranah domestic kearah public dan menyentuh berbagai aspek kehidupan seperti hukum, sosial dan ekonomi dari pelaku dan korban yang terdapat dalam suatu rumah tangga. Kekerasan dalam rumah tangga merupakan hal yang dialami oleh semua lapisan masyarakat. Mulai dari kelompok elit politik, pelaku seni atau yang lebih di kenal dengan selebriti hingga masyarakat di kelas bawah seperti pedagang asongan baik mereka sebagai pelaku atau korban dari kekerasan tersebut. Sebagian besar kasus memunculkan laki-laki sebagai pelaku sementara perempuan dan anak sebagai korban. Dalam Undang-Undang Penghapusan Kekerasan Dalam Rumah Tangga No 23 Tahun 2004, kekerasan dalam rumah tangga (KDRT) diartikan sebagai setiap perbuatan terhadap seseorang, yang berakibat timbulnya kesengsaraan atau penderitaan secara fisik, seksual, psikologis, dan/atau penelantaran rumah tangga termasuk ancaman untuk melakukan perbuatan, pemaksaan, atau perampasan kemerdekaan secara melawan hukum dalam lingkup rumah tangga. ${ }^{1}$ Oleh karena itu, artikel ini mengkaji

\footnotetext{
${ }^{1}$ Undang-Undang Penghapusan Kekerasan Dalam Rumah Tangga Nomor 23 Tahun 2004 pasal 1
} 
persepsi dan respon para pelaku kekerasan dalam rumah tangga terhadap UU PKDRT.

Sejak disahkannya UU PKDRT nomor 23 tahun 2004 beberapa pihak menyatakan bahwa jumlah kasus KDRT semakin menurun sementara pihak lain menerima pengaduan dengan jumlah lebih dibanding sebelum keberadaan UU PKDRT. Seperti LBH APIK (Lembaga Bantuan Hukum Asosiasi Perempuan Indonesia untuk Keadilan) Jakarta pada tahun 2004 telah menerima 817 pengaduan kasus KDRT. Jumlah ini meningkat secara signifikan dimana pada tahun sebelumnya yayasan ini menerima 627 pengaduan. ${ }^{2}$ Hal ini dapat dikatakan sebagai bukti dari meningkatnya kesadaran masyarakat atas pemahaman mereka terhadap kasus KDRT. Sementara di sisi yang lain, lembaga berbeda dalam naungan yayasan yang sama, LBH Jakarta pada tahun 2005 menyatakan bahwa kasus KDRT menurun sebanyak 57 kasus. Penurunan jumlah ini disebabkan oleh kesadaran hukum masyarakat atas UU PKDRT sehingga para pelaku berfikir ulang untuk melakukan perbuatannya. ${ }^{3}$ Jumlah kasus yang menurun berdasarkan data tersebut memberikan gambaran bahwa adanya serta implementasi UU PKDRT memberikan konsekuensi atau dampak kepada perilaku hukum masyarakat.

Dalam konteks kabupaten Malang, KDRT merupakan salah satu isu bidang hukum yang cukup signifikan untuk diperhatikan. Pengadilan Agama Kabupaten Malang mencatat jumlah tindak KDRT sebagai penyebab perceraian meningkat dari tahun ke tahun. Apabila pada tahun 2012, ditemukan 958 perceraian yang dipicu oleh tindak KDRT, maka pada Tahun 2013 -hingga bulan agustus- telah tercatat 1151 kasus perceraian yang dipicu oleh KDRT. Tindakan kekerasan dalam rumah tangga tersebut antara lain berbentuk Poligami yang tidak sehat, Ketidak cukupan ekonomi, tidak adanya tanggung jawab, kekejaman jasmani, dan kekejaman Mental.

Dari 272 kasus yang ditangani oleh unit Pelayanan Perempuan dan Anak (PPA)

\footnotetext{
${ }^{2}$ La Jamaa dan Hadidjah, Hukum Islam dan Undang-Undang Anti Kekerasan Dalam Rumah Tangga, (Surabaya: PT. Bina Ilmu, 2008), h. 40

${ }^{3}$ La Jamaa dan Hadidjah, Hukum... h. 40
}

Polresta Malang, 256 kasus lain merupakan kasus kekerasan suami terhadap istri. ${ }^{4}$ Sementara itu, Kantor Pelayanan Terpadu Pemberdayaan Perempuan dan Anak (P2TP2A) Kabupaten Malang mengungkapakan bahwa pada tahun 2012, telah terjadi 350 kasus kekerasan terhadap perempuan. $^{5}$ data tersebut menunjukkan bahwa suami atau laki-laki menjadi jenis kelamin atau pihak yang mendominasi sebagai pelaku tindak kekerasan dalam rumah tangga di kabupaten Malang.

Apabila beberapa data menunjukkan bahwa terjadi peningkatan pelaporan kasus KDRT sebagai bukti peningkatan kesadaran korban KDRT yang sebagian besar merupakan perempuan, maka yang menjadi pertanyaan adalah apakah keberadaaan dan implementasi UU PKDRT berhasil menyadarkan para suami atau pelaku (bagi sebagian pelaku selain suami seperti istri, majikan,dan lain-lain) yang seringkali berposisi sebagai pelaku akan buruknya tindakan Kekerasan Dalam Rumah Tangga. LBH Jakarta menyatakan bahwa jumlah kasus KDRT telah menurun, akan tetapi tetap saja pelaku yang muncul didominasi oleh para lelaki atau suami. Hal ini perlu diperhatikan mengingat UU PKDRT telah disahkan dan diberlakukan hampir 10 tahun lamanya.

Zulkarnain $^{6}$, mengutip pendapat Friedman, menjelaskan bahwa proses penegakan hukum membutuhkan kerjasama dan penguatan terhadap 3 unsur dalam sistem hukum. Pertama, struktur hukum (legal structure) berupa keberadaan lembaga-lembaga yang bertugas dalam pembentukan dan penegakan hukum. Dalam hal ini Indonesia memiliki banyak institusi dan lembaga yang berperan

4 Pelaporan Kasus KDRT Minim, (Online), (http://surabayapagi.com/index.php?read=PelaporanKasus-KDRT

Minim;3b1ca0a43b79bdfd9f9305b81298296214d3e93 2d0fee042d571bcf8c163a9f5 diakses pada 18 Agustus 2013)

5350 Kasus Kekerasan Terjadi di Malang, (Online),

(http://www.beritajatim.com/detailnews.php/4/.../20 13-02-

12/161569/350 Kasus Kekerasan Perempuan_Terjad i di Malang diakses pada 24 Agustus 2013)

${ }^{6}$ Zulkarnain, Praktik Peradilan Pidana, (Malang: Setara Press, 2013) h. 7 
dalam advokasi kasus KDRT. Terlepas dari kualitas kinerjanya, lembaga negara seperti komnas perempuan, BKBPM (Badan Keluarga Berencana dan Pemberdayaan Masyarakat, atau unit PPA (Pelayanan Perempuan dan Anak) di kepolisian merupakan bentuk dari keberadaan struktur hukum di Indonesia. Kedua, substansi hukum (legal substance) berupa keberadaan norma dan aturan baik secara lokal maupun nasional. Undang-undang PKDRT nomor 23 tahun 2004 merupakan bukti dari terpenuhinya unsur ini dalam sistem hukum Indonesia. Ketiga, Budaya hukum (legal culture) yang berupa pandangan dan perilaku masyarakat atas sistem hukum tersebut. Bila pemenuhan kedua unsur sebelumnya sebagian besar dipengaruhi oleh peran pemerintah, maka unsur ketiga lebih dipengaruhi pemenuhannya oleh sikap masyarakat dalam merespond dan mematuhi hukum itu sendiri.

Soerjono Soekanto mengingatkan bahwa sebuah sistem hukum atau aturan hukum harus memperhatikan beberapa hal dalam perumusannya agar dapat dipatuhi dan direspon secara positif oleh masyarakat. Hal ini berkaitan erat dengan fungsi hukum dalam mengubah masyarakat. Pertama, hukum tersebut harus bersifat tetap dan bukan ad-hoc atau sementara. Kedua, hukum harus jelas dan diketahui oleh warga masyarakat yang kepentingan-kepentingannya diatur dalam hukum tersebut. Ketiga, menghindari pembuatan aturan yang bersifat retreoaktif. Keempat, harus dimengerti oleh umum. Kelima, tidak ada peraturan yang saling bertentangan. Keenam, pembentukan hukum harus memperhatikan kemampuan warga masyarakat untuk mematuhi aturan tersebut. Ketujuh, menghindari perubahan-perubahan yang terlalu banyak. Kedelapan, adanya korelasi antara hukum dan penerapannya. ${ }^{7}$

Pemenuhan kedelapan hal tersebut tentu bergantung kepada kinerja dari pemerintah selaku struktur hukum dalam merumuskan dan mensosialisasikan perundang-undangan. Kampanye dan tindakan advokasi terhadap isu KDRT telah dilakukan. Tidak hanya oleh pemerintah, berbagai organisasi masyarakat

7 Soerjono Soekanto, Pokok-Pokok Sosiologi Hukum, (Jakarta: PT Raja Grafindo Persada, 2007) h. 149 sipil pun turut serta bahkan memiliki andil yang sangat signifikan dalam usaha mengatasi KDRT. Sosialisasi serta penyuluhan kepada masyarakat kerapkali diklaim telah dilakukan. Penyiaran kasus KDRT di berbagai media pun kerapkali ditampilkan. Melalui berbagai sarana tersebut diharapkan seluruh masyarakat paham atas isu kekerasan dalam rumah tangga.

Akan tetapi, seperti telah dijelaskan sebelumnya, bahwa jumlah kasus KDRT masih terbilang cukup banyak dan masih didominasi oleh pelaku laki-laki. Bukan tidak mungkin apabila UU PKDRT tidak sepenuhnya dipahami bahkan tidak diterima oleh seluruh masyarakat utamanya kaum lakilaki. Hal ini dikuatkan dengan sejarah bangsa Indonesia yang sebagian besar merupakan masyarakat patriarkal. Dimana laki-laki selalu ditempatkan superior daripada perempuan. Sehingga ketika muncul UU PKDRT yang memiliki semangat untuk merubah budaya tersebut, masyarakat utamanya laki-laki tidak dapat sepenuhnya menerima. Bahkan, sangat dimungkinkan bahwa mereka tidak mengetahui keberadaan UU PKDRT. Sehingga mereka tidak mengetahui konsekuensi apa yang mereka terima ketika melakukan kekerasan dalam rumah tangga. Hal-hal tersebut tentu akan memperlambat perwujudan budaya hukum yang berkualitas. Latar belakang lain yang penting untuk diperhatikan juga terhadap konteks penelitian ini adalah bagaimana pelaku memahami dan memandang UU PKDRT sebagai sebuah payung hukum yang mengatur perilaku mereka untuk tidak melakukan KDRT. Oleh karena itu, maka penting untuk melihat dan menganalisa bagaimana persepsi atau pendapat pelaku KDRT terhadap UU PKDRT sendiri. Hal tersebut yang melatar belakangi penelitian ini dilakukan.

\section{Metode Penelitian}

penelitian ini tergolong sebagai penelitian empiris yang mengungkapkan implementasi hukum yang hidup (living law) dalam masyarakat. $^{8}$ Dalam hal ini ialah respon atau persepsi masyarakat Kabupaten Malang khususnya suami atau pelaku KDRT terhadap UU PKDRT. Pendekatan penelitian ini

8 Pedoman Penulisan Karya Ilmiah, (Malang: Fakultas Syariah, 2012), h. 44 
menggunakan pendekatan kajian hukum sosiologis (Socio-legal Reserach). Pendekatan ini menempatkan hukum sebagai variable bebas yang menimbulkan pengaruh dan akibat pada aspek kehidupan sosial. ${ }^{9}$ Pendekatan ini digunakan untuk melihat respon dan pemahaman suami terhadap keberadaan UU PKDRT no 23 tahun 2004.

Penelitian ini bertempat di Kabupaten Malang Provinsi Jawa Timur. Pemilihan lokasi penelitian mempertimbangkan bahwa Kabupaten Malang memiliki tingkat perceraian dengan kategori cerai gugat yang cukup tinggi di Jawa timur bahkan di Indonesia. Dengan tingginya angka cerai gugat, maka diasumsikan bahwa banyak istri yang kecewa dengan sang suami dengan berbagai faktor yang berbeda-beda. Seperti dijelaskan sebelumnya, pada tahun 2012, sebagian besar kekecewaan tersebut masuk dalam kategori kekerasan ekonomi dan psikis dalam rumah tangga. Selain itu begitu banyaknya laporan KDRT dari tahun ke tahun yang diterima oleh Kantor Pelayanan Terpadu Pemberdayaan Perempuan dan Anak (PLTP2A) Kabupaten Malang.

Alasan lain pemilihan Kabupaten Malang adalah status kabupaten Malang sebagai kota pendidikan. Malang dikenal sebagai kota pendidikan dengan jumlah perguruan tinggi negeri maupun swasta yang cukup banyak. Kabupaten Malang juga menjadi lokal kerja bagi begitu banyak lembaga yang concern pada advokasi kasus kekerasan dalam rumah tangga. Sebut saja seperti Woman Crisis Center (WCC), Pusat Studi Gender (PSG UIN Malang), LBH Malang, Kantor Pelayanan Terpadu Pemberdayaan Perempuan dan Anak (PLTP2A) Kabupaten Malang, dan lembagalembaga lainnya. Kondisi ini secara kasat mata tentu akan sangat membantu dalam memaksimalkan kampanye UU PKDRT. Lebih tepatnya, penelitian ini mengambil lokasi Lembaga Pemasyarakatan Lowokwaru Malang sebagai tempat pengambilan sample atau informan. Lowokwaru adalah sebuah kecamatan di Kota Malang, Jawa Timur.

Penelitian ini menggunakan dua jenis sumber data. Pertama, sumber data primer berupa informasi langsung dari para

\footnotetext{
${ }^{9}$ Amiruddin, Pengantar Metode Penelitian Hukum, (Jakarta: PT Raja Grafindo Persada, 2010) h. 133
}

informan. Para informan ini merupakan para pelaku KDRT yang menyebabkan sang istri menjadikannya sebagai alasan perceraian atau terpidana KDRT. Pada penelitian ini, peneliti melakukan teknik purposive random sampling dalam memilih informan untuk kebutuhan pengumpulan data. 4 orang narapidana dengan kasus atau dakwan pelaku KDRT dipilih sebagai informan berdasarkan rekomendasi petugas lapas berdasarkan prosedur yang ditentukan oleh Lapas Lowokwaru

Kedua, sumber data sekunder yang terbagi kepada bahan hukum primer dan bahan hukum sekunder. Bahan hukum primer berupa aturan-aturan pemerintah yang berkaitan dengan penghapusan kekerasan dalam rumah tangga. Bahan hukum sekunder berupa hasil penelitian serta buku-buku yang menjelaskan tentang tindak kekerasan, khususnya yang terjadi dalam rumah tangga. ${ }^{10}$

\section{HASIL DAN PEMBAHASAN}

Keberadaan UU PKDRT no 23 tahun 2004 merupakan sebuah refleksi atas penderitaan berkepanjangan para kaum perempuan dan anak dalam rumah tangga. Pada tahun 2000, Kementrian Negara Pemberdayaan Perempuan mencatat bahwa lebih dari $10 \%$ wanita, atau 24 juta wanita di Indonesia pernah mengalami tindak kekerasan. Bentuk kekerasan tersebut didominasi oleh kekerasan dalam rumah tangga. ${ }^{11}$ Perserikatan bangsabangsa merilis bahwa satu dari tiga perempuan pernah mengalami kekerasan. Sementara itu, 57\% kekerasan di Turki dilakukan oleh pasangannya. Bahkan di negara seperti Inggris, satu dari empat wanita pernah mengalami kekerasan oleh pasangan intimnya. $^{12}$

Sementara secara teoritis dijelaskan bahwa perilaku kekerasan merupakan potensi yang dimiliki oleh semua orang. Erich Form mengaitkan perilaku kekerasan dengan rasa frustasi. Frustasi diartikan sebagai perasaan yang muncul ketika keinginan atau suatu harapan tidak tercapai. Perasaan semacam ini akan mengarahkan si perasa untuk melakukan

10 Soerjono Soekanto, Pengantar Penelitian Hukum, (Jakarta: UI-Press, 2006) h. 52

${ }^{11}$ La Jamaa dan Hadidjah, Hukum.., h.23

${ }^{12}$ La Jamaa dan Hadidjah, Hukum.., h.24 
kekerasan (aggression). ${ }^{13}$ Konsep ini sangat cocok untuk kemudian menjelaskan kasuskasus di mana suami menganiyaya istri karena tidak menuruti perintahnya.

Selain itu, Albert Bandura seperti dikutip oleh La Jamaa, mengajukan penjelasan lainnya yang dikenal sebagai teori SocialLearning. Sesuai namanya, teori ini mengaitkan tindak kekerasan seseorang dengan lingkungan atau role model si pelaku. Ketika lingkungannya menunjukkan begitu banyak aksi kekerasan, ditambah dengan role model si pelaku yang menjadi salah satu pelakunya, maka sangat dimungkinkan bagi si pelaku untuk menirunya. ${ }^{14}$ Harus menjadi koreksi serius bagi kita semua untuk tidak melakukan atau mempertontonkan tindak kekerasan. Karena berpotensi menjadi contoh bagi orang-orang disekitar kita.

Michel Foucault mengaitkan antara tindak kekerasan dengan relasi kekuasaan. Ketika seseorang merasa menguasai seseorang, maka ia merasa berhak untuk melakukan segala hal kepada orang tersebut. ${ }^{15}$ Konsep inilah yang sering dijadikan penjelasan mengapa marak terjadi kekerasan di dalam rumah tangga. Budaya parthriarkal bangsa Indonesia dan dunia telah menempatkan lelaki untuk merasa bahwa dia memiliki wanita dan berhak melakukan apapun kepadanya.

Semua teori tersebut menuntut adanya perubahan sistem sosial masyarakat untuk mengurangi tindak kekerasan dalam rumah tangga. Mindset bahwa wanita adalah makhluk nomor dua, bahwa wanita adalah milik laki-laki, harus segera dirubah. Untuk melakukan perubahan tersebut dibutuhkan suatu sistem hukum yang memaksa masyarakat untuk melakukan perubahan. Undang-undang penghapusan kekerasan dalam rumah tangga hadir untuk memenuhi kebutuhan tersebut.

Hukum Sebagai Alat untuk Mengubah Masyarakat

Soerjono Soekanto membuktikan bahwa selama ini hukum telah berhasil mengubah masyarakat. Seperti kehadiran UndangUndang No 22 Tahun 1961 tentang jumlah

${ }^{13}$ Form, The Anatomy of Human destructiveness. (Holt, Rinehart, and Winston : 1973) h. 67

${ }^{14}$ La Jamaa dan Hadidjah, Hukum..., h.57

${ }^{15}$ La Jamaa dan Hadidjah, Hukum..., h.61 universitas dan mahasiswa di Indonesia. Setelah kehadiran undang-undang ini, jumlah perguruan tinggi serta jumlah mahasiswa melonjak naik. Dari yang awalnya hanya 14 universitas, kemudian meningkat menjadi 35 universitas setelah kemunculan peraturan tersebut. $^{16}$

Meski demikian, bukan berarti hukum kemudian akan dengan pasti diterima dan ditaati oleh masyarakat. Ada beberapa faktor yang memungkinkan untuk hukum tersebut tertolak oleh masyarakat. Pertama, tidak mengerti kegunaan unsur-unsur baru tersebut (hukum/aturan). Kedua, perubahan itu sendiri (yang diinginkan oleh hukum) bertentangan dengan kaidah dan nilai-niliainya yang ada dan berlaku. Ketiga, ada kepentingan masyarakat yang berkuasa untuk menolak proses pembaharuan. Keempat, resiko untuk melakukan perubahan lebih besar dari mempertahankan keadaan sebelumnya. Kelima, masyarakat tidak mengakui wewenang pelopor perubahan (pembuat hukum). ${ }^{17}$

Sangat terlihat kemudian, bahwa pemahaman masyarakat atas sebuah aturan sangatlah penting untuk melakukan perubahan yang dimaksud. Bila masyarakat tidak mengerti manfaat yang akan mereka terima dari aturan tersebut, maka sangat kecil kemungkinan bagi mereka untuk mematuhinya. Akan lebih parah lagi jika mereka bukan tidak paham mengenai aturan tersebut, akan tetapi justru tidak mengetahui keberadaan aturan tersebut. Bagaimana akan paham bila aturannya saja tidak tahu.

Oleh karenanya, Prof. Soerjono menegaskan kepada para pembuat kebijakan untuk memperhatikan 8 poin penting berkaitan dengan pembuatan dan implementasi hukum. Pertama, hukum tersebut harus bersifat tetap dan bukan ad-hoc atau sementara. Kedua, hukum harus jelas dan diketahui oleh warga masyarakat yang kepentingan-kepentingannya diatur dalam hukum tersebut. Ketiga, menghindari pembuatan aturan yang bersifat retreoaktif. Keempat, harus dimengerti oleh umum. Kelima, tidak ada peraturan yang saling

\footnotetext{
${ }^{16}$ Soerjono Soekanto, Pokok..., h.123

${ }^{17}$ Soerjono Soekanto, Pokok..., h.128-129
} 
bertentangan. Keenam, pembentukan hukum harus memperhatikan kemampuan warga masyarakat untuk mematuhi aturan tersebut. Ketujuh, menghindari perubahan-perubahan yang terlalu banyak. Kedelapan, adanya korelasi antara hukum dan penerapannya.18

Meski bukan satu-satunya konsep untuk membuat hukum diterima oleh masyarakat, kedelapan poin ini haruslah diperhatikan oleh struktur hukum. Sehingga hukum yang dirumuskan benar-benar dapat menjadi alat untuk melakukan perubahan sosial.

\section{UU PKDRT menurut pelaku KDRT}

Apabila melihat hasil wawancara di atas, maka dapat kita lihat bahwa seluruh informan mengakui bahwa UU PKDRT sudah cukup baik. Bahkan beberapa menyesal tidak mengetahui keberadaan undang-undang tersebut. Seperti informan I yang mengaku sama sekali tidak mengetahui keberadaan UU PKDRT menyatakan menyesal. Seandainya Ia tahu bahwa ada UU PKDRT, sangat mungkin baginya untuk tidak melakukan perselingkuhan tersebut. Hal ini tergambar dari pernyataan informan I sebagai berikut "Enggeh pun bagus pak, kulo niku khilaf, lek kulo pung ngertos, gag mungkin kulo selingkuh," ujar informan.

Begitu juga dengan informan IV yang mengaku menyesal dengan ketidak tahuannya tentang UU PKDRT. Bahkan seandainya Ia nanti diberi kesempatan untuk membangun rumah tangga lagi, tentu dia akan menghindari untuk melakukan tindakan KDRT.

Sementara itu, dua informan lainnya mengaku telah tahu, akan tetapi ada kondisikondisi di mana UU tersebut tidak lagi dipikirkan. Seperti yang dialami oleh informan II di mana Ia memergoki sang istri tengah berduaan dengan laki-laki lain di dalam kamarnya. Parahnya, si laki-laki tidak menggunakan pakaian atas. Hal ini tentu mengakibatkan kemarahan serta kekalapan informan II. Sehingga Ia bergegeas mengambil parang dan kemudian menyerang si laki-laki. Hanya sayang meleset dan justru terkena sang anak yang baru berumur 40 hari.

Sementara itu, bagi informan III, Ia sudah mengetahui keberadaan UU PKDRT. Bahkan Ia menyatakan bahwa UU PKDRT cukup bagus. Akan tetapi, Ia tidak merasa telah melakukan sebuah kekerasan. Karena perselingkuhan yang Ia lakukan sejatinya telah diijinkan oleh sang istri dan si selingkuhan. Keduanya bersedia untuk dimadu oleh informan III. Jika dikategorikan, didapat informasi seperti pada tabel di bawah ini:

\begin{tabular}{|c|c|c|c|c|}
\hline & Kasus & Pengetahuan & Sikap & Tanggapan \\
\hline $\begin{array}{l}\text { Informan } \\
\text { I }\end{array}$ & $\begin{array}{l}\text { Berselingkuh } \\
\text { dengan anak tiri }\end{array}$ & Tidak Tahu & $\begin{array}{l}\text { Menerima } \\
\text { keberadaan UU } \\
\text { PKDRT }\end{array}$ & $\begin{array}{l}\text { Seandainya Ia tahu } \\
\text { keberadaan UU PKDRT } \\
\text { sebelumnya, maka Ia } \\
\text { tidak akan melakukan hal } \\
\text { tersebut (selingkuh anak } \\
\text { tiri) }\end{array}$ \\
\hline $\begin{array}{l}\text { Informan } \\
\text { II }\end{array}$ & $\begin{array}{l}\text { Membacok (tidak } \\
\text { sengaja) anak }\end{array}$ & Tahu & $\begin{array}{l}\text { Menerima } \\
\text { keberadaan UU } \\
\text { PKDRT }\end{array}$ & $\begin{array}{l}\text { Ia tahu, akan tetapi tetap } \\
\text { ada kondisi di mana } \\
\text { aturan akan dilupakan } \\
\text { dan diabaikan }\end{array}$ \\
\hline $\begin{array}{l}\text { Informan } \\
\text { III }\end{array}$ & Selingkuh & Tahu & $\begin{array}{l}\text { Menerima } \\
\text { keberadaan UU } \\
\text { PKDRT }\end{array}$ & $\begin{array}{l}\text { Ia tahu dan tidak merasa } \\
\text { apa yang Ia lakukan } \\
\text { merupakan bentuk KDRT }\end{array}$ \\
\hline $\begin{array}{l}\text { Informan } \\
\text { IV }\end{array}$ & Membunuh Istri & Tidak Tahu & $\begin{array}{l}\text { Menerima } \\
\text { keberadaan UU } \\
\text { PKDRT }\end{array}$ & $\begin{array}{l}\text { Ia tidak akan cekcok lagi } \\
\text { dengan istrinya di masa } \\
\text { depan karena keberadaan } \\
\text { UU PKDRT ini. }\end{array}$ \\
\hline
\end{tabular}

\footnotetext{
${ }^{18}$ Soerjono Soekanto, Pokok, h. 149
} 


\section{Implementasi UU PKDRT di Kabupaten Malang}

Soerjono Soekanto mensyaratkan apabila sebuah hokum ditujukan untuk mengubah perilaku masyarakat. Maka setidaknya Ia harus memenuhi beberapa persyaratan. Soerjono memberikan setidaknya delapan syarat. ${ }^{19}$ Pertama, Hukum merupakan aturanaturan umum yang tetap, jadi bukan merupakan aturan yang bersifat ad-hoc. Hal ini diwujudkan dengan keberadaan UndangUdang PKDRT yang telah lama disahkan dan diberlakukan. Setidaknya undang-undang ini telah diberlakukan selama kurang lebih 9 tahun lamanya. Jadi, dapat dikatergorikan sebagai undang-undang atau aturan umum yang bersifat tetap. Selain itu, beberapa peraturan perundangan lainnya juga turut mendukung rigiditas dari undang-undang penghapusan kekerasan dalam rumah tangga ini. Seperti undang-undang hak asasi manusia, bahkan undang-undang dasar 1945. Kedua, hukum tersebut harus jelas dan diketahui oleh warga masyarakat yang kepentingankepentingannya diatur oleh hukum tersebut. Pada point ini, dapat kita lihat bahwa undangundang penghapusan kekerasan dalam rumah tangga menggunakan bahasa indonesia yang dalam hal ini merupakan bahasa nasional Indonesia. Sehingga selayaknya dapat diketahui oelh masyarakat seluruhnya. UU PKDRT juga telah disosialisasikan melalui berbagai media baik secara sengaja maupun tidak. Seperti melalui seminar-seminar, ataupun sebatas tayangan infotaiment.

Ketiga, menghindari penerapan aturanaturan yang retreoaktif .Salah satu asas hukum ialah asas legalitas atau asas nonretroaktif yang berarti bahwa suatu tindakan dihukumi dengan peraturan yang telah ada sebelum atau saat tindakan itu dilakukan. Sehingga, tidak bisa apabila aturan yang dibuat pada tahun 2012, digunakan untuk menghukum perbuatan yang dilakukan pada tahun 2000. Karena hal ini akan menimbulkan kerancuan. Siapa yang akan tahu apa saja hal yang dilaranga pada aturan di tahun 2015. Sementara kita masih hidup di tahun 2013. Keempat, Hukum tersebut harus dimengerti oleh umum. Pengetahuan dan pemahaman masyarakat atau umum tentu akan sangat mempengaruhi dipatuhi atau tidaknya suatu aturan tersebut. Bagaimana bisa sebuah aturan akan dilaksanakan sementara yang diatur atau masyarakat umum tidak paham apa isi aturan itu sebenarnya. Kelima, tidak ada aturan yang saling bertentangan apabila terdapat aturanaturan yang saling bertentangan, maka tentunya akan mengakibatkan kebingungan dalam penerapannya. Meski kedua aturan atau bebrapa aturan tersebut diketahui oleh masyarakat umum, akan tetapi akan menimbulkan kebingungan aturan mana yang harus digunakan. Dalam hal ini UU PKDRT tampaknya tidak memiliki pertentangan vital dengan beberapa perundangan lainnya.

Keenam, Pembentukan hukum harus memperhatikan kemampan warga masyarakat untuk mematuhi hukum tersebut UndangUndang PKDRT tampaknya sudah cukup baik melihat kondisi dan kemampuan masyarakat. Tidak ada aturan yang disusun yang mustahil untuk dilakukan. Tinggal bagaimana peran negara membantu masyarakat untuk memenuhi kesemua itu. Ketujuh, perlu dihindarkan terlalu banyaknya perubahan-perubahan pada hukum, oleh karena warga masyarakat dapat kehilangan ukuran dan pegangan bagi kegiatankegiatannya. Hal ini tidak jauh berbeda dengan point pertama yang mensyaratkan keberadaan aturan-aturan yang tetap dan bukan ad-hoc. Begitu pula aturan atau undang-undang PKDRT harus disusun sesuai dengan kebutuhan masyarakat. Sehingga, tidak perlu dilakukan perubahan-perubahan dipertengahan yang mengakibatkan kaburnya aturan hukum itu sendiri. Kedelapan, adanya korelasi antara hukum dengan pelaksanaan atau penerapan hukum tersebut. Dapat juga dikatakan bahwa pelaksanaan aturan dengan aturan yang ada haruslah sesuai dan tidak bertentangan. Jangan sampai UU PKDRT telah menjamin hak untuk mendapatkan pelayanan khusus terhadap korban, akan tetapi nyatanya tidak terjadi pelaksanaannya di lapangan. Hal-hal semacam ini harus diperhatikan oleh aparatur negara yang berfungsi sebagai the guardian of law.

\footnotetext{
${ }^{19}$ Soerjono, Pokok..., 149
} 


\section{Proses Penegakan Hukum Dalam Konteks Penghapusan Kekerasan Dalam Rumah Tangga di Kabupaten Malang}

Lawrence Friedman mensyaratkan kehadiran 3 unsur demi tegaknya atau berjalannya suatu hukum. Pertama, adanya struktur hukum atau lembaga-lembaga serta aparatur negara yang bertugas melaksanakan dan mengawasi berjalannya aturan tersebut. Kedua, sbstansi hukum atau aturan itu sendiri yang akan digubakan sebagai acuan dalam pelaksanaan. Ketiga, legal culture atau budaya hukum yang tercakup di dalamnya pengetahuan serta sikap masyarakat atas keberadaan aturan tersebut.

Malang raya sejatinya memiiki beberapa lembaga yang berfokus dalam advokasi kasus-kasus KDRT, baik lembaga tersebut berada dalam naungan pemerintahan ataupun independen. Seperti kepolisian yang memiliki unit khusus Pelayanan Perempuan Anak (PPA), atau Komnas Perempuan dan BKBPM (Badan Keluarga Berencana dan Pemberdayaan Masyarakat. Sementara lembaga independen seperti Women Crisis Center, P2TP2A, dan Pusat Studi Gender UIN malang juga mengambil peran dalam penegakan UU PKDRT.

Setelah penyampaian beberapa data di atas, dapat kita lihat dan ketemukan bahwa masih ada kelemahan-kelemahan baik dari segi legal structure, legal substantion, dan legal culture dalam implementasi UU PKDRT. Dari segi aparatur penegak hukum tampaknya tidak melakukan sosialisasi secara merata kepada masyarakat. Terbukti 2 dari 4 informan tidak mengetahui tentang keberadaan UU PKDRT. Bahkan Informan III meski tahu, tetapi tidak menganggap apa yang dia lakukan sebagai sebuah tindak kekerasan. Padahal perselingkuhan tentu merupakan sebuah bentuk kekerasan psikis yang sangat dalam bagi siapapun. Baik itu wanita maupun pria tidak akan rela atau paling tidak akan berusaha untuk memiliki pasangannya dan tidak ingin membaginya dengan siapa pun.

Terlihat bahwa pemerintah tidak menggunakan tokoh-tokoh masyarakat dalam mendukung terealisasinya UU PKDRT. Akan sangat efektif tampaknya untuk melaksanakan pertemuan-pertemuan dengan skala kecil memanfaatkan PKK, Forum Tahlilan, atau khutbah subuh untuk mensosialisasikan UU PKDRT atau aturan-aturan lainnya. selama ini pemerintah sebagai legal structure terkesan lebih nyaman 'menunggu bola'. Artinya hanya menunggu laporan masuk, baru bertindak. Harusnya, pemerintah menggunakan berbagai media yang ada untuk lebih mensosialisasikan UU PKDRT. Berkenaan dengan substansi hukum, masih belum ditemukan masalah yang fatal di dalamnya. Hanya saja akan sangat baik apabila setiap daerah memiliki aturan PKDRT masing-masing yang sesuai dengan kondisi daerahnya. Tentu tanpa menafikan UU PKDRT yang telah ada di atasnya.

Berkenaan dengan legal culture atau budaya hukum yang sangat erat kaitannya dengan penegtahuan masyarakat, dapat terlihat bahwa masih ada mereka-mereka yang berkepentingan tidak mengetahui tentang keberadaan aturan ini. Padahal, menurut Soejono Soekanto, agar aturan tersebut dapat terlaksana, aturan tersebut harus diketahui warga masyarakat yang berkepentingan.

Bagi para pelaku KDRT yang dalam penelitian ini direpresentasikan oleh para narapidana Lapas Lowokwaru, Malang. UU PKDRT bagi mereka sudah sangat baik dan bagus. Mereka pun bersikap menerima dan mendukung keberadaan UU tersebut. Mari kita lihat pernyataan-pernyataan mereka

Meski demikian, sangat disayangkan bahwa pemahaman atas UU PKDRT mereka masihlah berbeda-berbeda. ada yang paham cukup dalam, ada pula yang tampaknya hanya paham dalam tataran permukaan. Seperti informan III yang tidak memahami bahwa perselingkuhan yang Ia lakukan dapt dikategorikan sebagai KDRT secara psikis meski akhirnya mendapat izin dari kedua belah pihak yaitu sang istri dan si selingkuhan. Sementara bagi informan IV, tampaknya setelah didakwa atas tindak pidana KDRT Ia telah mulai paham bahwa percekcokan juga merupakan kategori KDRT, yakni kekerasan verbal. Hal ini diindikasikan dengan pernyataan kapoknya dan keengganannya utuk kembali cekcok apabila memiliki istri lagi di masa depan. 
156 de Jure, Jurnal Syariah dan Hukum, Volume 6 Nomor 2, Desember 2014, hlm. 148-156

\section{Kesimpulan}

Berdasarkan uraian-uraian tersebut, ada beberapa kesimpulan yang dapat diambil oleh peneliti yaitu sebagai berikut; Pertama, Pandangan dan sikap pelaku KDRT terhadap UU PKDRT dibentuk atau dipengaruhi berdasarkan pengetahuan pelaku terhadap adanya UU PKDRT yang mengatur persoalan kekerasan dalam rumah tangga baik jenis maupun sanksi atau hukuman yang akan didapat. Kedua, jika pelaku sudah mengetahui adanya UU KDRT, pelaku bersikap respek dan cenderung mau mentaati. Pada tingkat yang lebih serius lagi informan pada umumnya memiliki rasa taat terhadap UU PKDRT dan mereka memiliki rasa cemas jika melakukan tindak KDRT. Ketiga, berdasarkan hasil analisa data, penelitian ini menyimpulkan bahwa pada umumnya pelaku memiliki pandangan positif terhadap adanya serta isi dari UU PKDRT dengan alasan bahwa keberadaan sebuah aturan pada dasarnya baik dan tujuan mengatur kebaikan masyarakat.

\section{DAFTAR PUSTAKA}

\section{BUKU}

Amiruddin, Pengantar Metode Penelitian Hukum, Jakarta: PT Raja Grafindo Persada, 2010

Form, Erich. The Anatomy of Human destructiveness. Holt, Rinehart, and Winston : 1973

La Jamaa dan Hadidjah, Hukum Islam dan Undang-Undang Anti Kekerasan Dalam Rumah Tangga, Surabaya: PT. Bina Ilmu, 2008

Soekanto, Soerjono. Pokok-Pokok Sosiologi Hukum, Jakarta: PT Raja Grafindo Persada, 2007

Soekanto, Soerjono. Pengantar Penelitian Hukum, Jakarta: UI-Press, 2006

Zulkarnain, Praktik Peradilan Pidana, Malang: Setara Press, 2013
Keempat, sosialisasi UU PKDRT masih membutuhkan model dan cara yang dapat dijangkau sehingga subtansi UU PKDRT dapat dipahami. Isi materi dari UU PKDRT kadangkala tidak difahami secara subtantif dan teknis oleh pelaku KDRT. Kadangkala di masyarakat masih terjadi perbedaan interpretasi terhadap butir-butir atau poinpoin dari KDRT tersebut sehingga pelaku masih melakukan tindak KDRT karena menurut mereka apa yang mereka telah lakukan bukan bagian dari tindak KDRT.

Penelitian ini juga merekomendasikan adanya sosialisasi dari pemerintah dengan menggunakan berbagai media yang dapat diakses oleh seluruh lapisan masyarakat terkait dengan tindak kekerasan dalam rmah tangga serta konsekuensi hokumnya. Selain itu, dibutuhkan peran serta masyarakat atau keluarga terdekat dari korban atau pelaku KDRT dalam mengontrol terjadainya KDRT atau berlakunya UU PKDRT.

\section{UNDANG-UNDANG}

Undang-Undang Penghapusan Kekerasan Dalam Rumah Tangga Nomor 23 Tahun 2004

\section{WEBSITE}

Pelaporan Kasus KDRT Minim, (Online) (http://surabayapagi.com/index.php?rea d=-Pelaporan-Kasus-KDRT-

Minim;3b1ca0a43b79bdfd9f9305b8129 8296214d3e932d0fee042d571bcf8c163 a9f5 diakses pada 18 Agustus 2013)

350 Kasus Kekerasan Terjadi di Malang, (Online)

(http://www.beritajatim.com/detailnews .php/4/.../2013-02-

12/161569/350_Kasus_Kekerasan_Pere mpuan_Terjadi_di_Malang diakses pada 24 Agustus 2013) 